\title{
Customer Relationship Management In Banking Sector Case Study Of Conventional Banks
}

\author{
Dennis Rydarto Tambunan ${ }^{1 *}$, Heru Kreshna Reza ${ }^{2}$, Melly Susanti ${ }^{3}$, Sabri $^{4}$ \\ ${ }^{1}$ Department of Management, Faculty of Economic, Dehasen Bengkulu University, Indonesia \\ ${ }^{2}$ Department of Accounting, Faculty of Economics and Business, Esa Unggul University, \\ Indonesia \\ ${ }^{3}$ Department of Accounting, Faculty of Economic, Dehasen Bengkulu University, Indonesia \\ ${ }^{4}$ Department of Management, Faculty of Economic, Istitut Teknologi dan Bisnis Haji Agus \\ Salim Bukittinggi Sumatera Barat, Indonesia \\ * Corresponding author: \\ Email: tambunandennis376@gmail.com
}

\begin{abstract}
.
The importance of Customer Relationship Management (CRM) to help businesses acquire new customers, retain existing ones and maximize their lifetime value. This paper discusses the role of Customer Relationship Management in 4 bank units and the need for Customer Relationship Management to increase customer value by using several analytical methods in CRM applications. This paper attempts to identify the technological revolution witnessed by commercial banks and to what extent it has benefited banks to build better customer relationship management (CRM) services between public sector banks and private sector banks. The purpose of this study is 1) to analyze customer opinions about bank CRM in relation to service quality management. 2) To find out the customer's opinion about the bank's CRM on customer relationship management. This study uses primary and secondary data. Primary data will be collected by distributing structured questionnaires to conventional banks (Private and Government). Secondary data will be collected from records published by the financial services authority (OJS), standard textbooks and published research papers, and through web information. The primary data required will be collected from 6 banks in Bengkulu. In addition to collecting information from banks, it also collects information from the general public who have bank accounts.
\end{abstract}

Keywords: Customer, Management, Relationship, Banking sector

\section{INTRODUCTION}

Competition in the financial services industry has increased in recent years. As technology changes and the deregulation of the financial industry, conventional banking is gradually being complemented by the emergence of the use of electronic banking. Bank customers prefer to use ATMs or websites instead of visiting branches, while technology has also reduced barriers to entry for new customers. Currently, customers have the power to choose the bank they like. Consequently, retaining existing customers, as well as attracting new ones, is an important concern for banks. Managing customers is at the core of Customer Relationship Management which 
allows banking companies to see the products offered by institutions and customers offer the most profitable products to customers. Customer relationship management (Customer Relationship Management) is a strategy that can help them build long-term relationships with their customers and increase their profits through proper management systems and implementation of customer-focused strategies (Suprapty et al., 2021). For many, Customer Relationship Management is a coordinated approach to the sales process that enables the various operational, customer contact, and sales promotion functions of an organization to function as a whole (Bright C. Opara, 2016).

Furthermore, these banks are very sensitive to the risks they face in dealing with money in the form of credit risk or market risk or operational risk. The Bank continues to embrace, passionately about the latest developments in customer relationship management and information and communication technology to serve better and earn more profit. Implementing a CRM system properly can provide many benefits for both the customer and the business. Banks have many customers and in order to meet the needs of their customers most of the banks have adopted CRM systems. CRM involves new and advanced marketing strategies that not only retain existing customers but also acquire new customers, (Sin et al., 2005) techniques such as this have been able to change the total output of the company. CRM is a discipline that enables companies to identify and target their most profitable customers (Bright C. Opara, 2016) Rianto et al., (2015) using variables identify, acquire, retain, develop and sustainable marketing in researching Customer Relationship Management and Its Effect on Customer Loyalty, found that all variables affect customer loyalty. Ogbadu \& Usman, (2012) research results that there is a direct relationship between customer relationship management and customer loyalty and bank profitability.

Customer satisfaction is an important variable in the evaluation and control of a bank's marketing management (Bright C. Opara, 2016). Poor customer satisfaction will lead to a decrease in customer loyalty, and given the extended offers from competitors, customers can easily switch banks (Keiningham et al., 2007). A close relationship with customers will require strong coordination between technology and marketing departments to provide long-term retention for selected customers. Banks need to make effective use of their customer relationships and make better use of customer information across institutions. Successful banks around the world have invested heavily in customer relationship management technology, which in turn will significantly increase bank profits on the one hand and increase the level of their customers doing business with them on the other (Bohling et al., 2006; Sanjaya). et al., 2015; Mittal \& Kumra, 2001; Ogbadu \& Usman, 2012). As a process that aims to collect customer data, find customer profiles and use customer knowledge in certain marketing activities (PB REDDY et al., 2012). Customer relationship management system (CRM) has been adopted to have a better relationship with customers by having detailed knowledge of their needs through the use of different information technologies. 
Providing high quality services is an important strategy to attract and retain customers in improving customer relationships in banks. pleasing customers and not only preventing them from getting poor service quality itself consists of several dimensions such as empathy, reliability, responsiveness, tangible, communication, (Karimi et al., 2006). Universally CRM performs efficient banking operations and the associated business involves managing; 1) information and communication technology that drives the bank's core business, 2) customer relations 3) risks associated with doing business with customers and other banks and financial institutions. Although banking is an old activity and has its roots in Economics, Finance and Trade, it is important to discuss the concept of Customer Relationship Management (CRM). This paper discusses the role of Customer Relationship Management in the banking sector and the need for Customer Relationship Management to increase customer value by using several analytical methods in CRM applications. This study aims to analyze customer opinions about bank CRM in relation to service quality management. And to find out customer opinions about the bank's CRM on customer relationship management. and retention management.

\section{METHODS}

This research work will rely on primary and secondary data. Primary data will be collected by distributing structured questionnaires to private and government banks (conventional banks). Secondary data will be collected from records published from OJS and other Bank authorities, standard textbooks and published research papers, and via web information. The primary data required will be collected from conventional bank branches, at least 6 branches will be approached, in addition to collecting information from banks, the general public who have accounts at private and government banks.Sampling Design Researchers followed multi-stage sampling in the selection of samples. Public and private sector banks operate in Bengkulu. The sample for this study was selected through a three-stage sampling procedure. The first stage involves the choice of a bank. Because it would be useful to try a comparative study between private and government banks. So the final sample for this study consisted of 6 bank branches that produced 50 customers to study customer relationship management in Bengkulu Private and Government banks.

The CRM process must fully support the basic steps of the customer life cycle.

The basic steps are:

1. Attracting current and new customers

2. Acquiring new customers

3. Serving customers Finally

4. retaining customers

The steps to be followed in minimizing work are

1. Identify the right CRM initiatives

2. Implement adequate technology to assist CRM initiatives 
3. Set standards (targets) for each initiative and everyone involved in the circle

4. Evaluate actual performance against standards or benchmarks

5. Take corrective action to correct deviations, if any

Analytical Data Collection Analytical

Data Information is customer centric and contains the following data:

1. Demographic (age, gender, cultural level, marital status, etc.)

2. Ownership of bank products/services

3. Product/service usage (balance, transactions, etc.)

4. Global variable : profit, costs, risks, assets, liabilities

5. Relationship with banks: segments, portfolios, etc.

\section{RESULT AND DISCUSSION}

Relationship marketing brings a new approach to customer relationships, while creating new market assumptions. CRM is a business strategy focused on maximizing shareholder value by winning, growing, and retaining the right customers. Here we distinguish two important elements. First of all, concentrate on the most important from the perspective of the company's customers and secondly maintain a long-term relationship with them. That's why it's important to collect customer opinions, complaints and consequent new needs. This way it is possible to approach clients on a more individual basis, and make them feel important to the company, because every company is as valuable as the customer. Satisfied clients will also recommend the company's products to their friends. The purpose of CRM in the Banking Sector is to enable banks to analyze customer behavior and their value. The main focus areas are such as customers, relationships, and relationship management. The main goals for implementing CRM in business strategy are:

1. To simplify marketing and sales processes

2. To make call centers more efficient

3. To provide better customer service

4. To find new customers and increase customer revenue 5. To cross-link more effective product selling

CRM helps banks to provide many benefits to their customers, some of the main benefits are as follows.

1. Provision of services throughout the life cycle of corporate customers, from the initial stage to the establishment of close long-term relationships with profitable clients

2. Optimization of the use of bank resources, such as alternative distribution channels (internet and banking houses),

3. Reduction and limitation of operational costs significantly through automation and standardization of the system, 
4. Low maintenance and expansion costs due to the use of modern administrative tools that allow bank employees to make various modifications to the system

5. CRM enables businesses to leverage information from their databases to achieve customer retention and to cross-contact sell new products and services to existing customers.

6. Companies that implement CRM make better relationships with their customers, achieve loyal customers and substantial returns, increase revenue, and reduce costs

In private banks the average value of individual attention to understanding customer specific needs is lower than the average value of the dimensions each. Public Sector Banks are rated higher than private sector banks and public sector banks are highly interactive with their customers' perceptions of customer retention management practices in the public and private sectors being almost the same.Customers' perceptions of service quality at private banks are lower. So it is suggested that private sector banks can take steps to improve their service quality, strategy, customer interaction management strategy, customer retention management strategy.

1. Challenges faced by banks in the successful implementation of CRM; 1. Difficulty getting a complete view of the customer

2. The need to move away from disjointed, standalone and inconsistent channels to provide a cohesive multi-channel offering 3. Disconnected legacy system loads and disparate databases that store client financial data.

3. The cost and complexity of meeting stringent government regulations and client security and privacy requirements.

4. Pressure on margins and growth prospects from increased competition. 6. Costs associated with retaining customers and developing customer loyalty.

While CRM can help banking institutions manage their customers efficiently, many banks fail to incorporate the concept into the prevailing work culture. But the high incidence of CRM failure has nothing to do with the concept of CRM itself. Usually the case of banks that do not pay attention to the customer data they already have.

\section{CONCLUSION}

In today's world, customers enjoy the complete luxury of customized technical solutions and the use of the same bank to strengthen long term mutually beneficial relationships. In order for banks to successfully adopt the CRM philosophy in running their business, bank management must first understand CRM as a holistic concept involving multiple interrelated disciplines, including market knowledge, strategic planning, business process improvement, product design and pricing analysis, technology implementation, management. human resources, customer retention, and sales management and training. The attempt here is to illustrate the importance of following CRM practices to acquire, retain and grow customers for sustainable success for the company and how it can be automated as an application practice with the help 
of an organization's IT infrastructure. The entire infrastructure combined with the knowledge it generates, guides the fate of the company in this highly competitive world. CRM forms the greatest strategic asset a company can have to effectively implement its marketing plans. This study provides some guidelines for customer relationship management satisfied customers are loyal customers, their retention rate is much higher and so is their overall profitability for the bank. CRM offers the most holistic route for banks to improve customer relationships.

\section{ACKNOWLEDGMENTS}

The authors would like to thank the private and government conventional banks in Bengkulu (BRI, BNI, BPD, Bank Danamon, Bank Pundi, BTPN) who have assisted us in this research. Thank you to all lecturers who have been involved in writing this article. Hopefully this article is useful for readers.

\section{REFERENCES}

[1] Bohling, T., Bowman, D., LaValle, S., Mittal, V., Narayandas, D., Ramani, G., \& Varadarajan, R. (2006). CRM implementation: Effectiveness issues and insights. Journal of Service Research, 9(2), 184-194. https://doi.org/10.1177/1094670506293573

[2] Bright C. Opara, D. N. O. (2016). Customer Relationship Management and Banking Sector Market Share performance. International Journal of Business and Management Invention, Volume 5 I(December), 13-21.

[3] Karimi, F., Technology, I., \& Tehran, U. (2006). A Conceptual Framework for Electronic Customer Relationship Management ( e-CRM ): A Strategic Approach. Emerging Trends and Challenges in Information Technology Management, 1, 706-709.

[4] Keiningham, T. L., Cooil, B., Aksoy, L., Andreassen, T. W., \& Weiner, J. (2007). The value of different customer satisfaction and loyalty metrics in predicting customer retention, recommendation, and share-of-wallet. Managing Service Quality: An International Journal, 17(4), 361-384. https://doi.org/10.1108/09604520710760526

[5] Mittal, R. K., \& Kumra, R. (2001). E-crm in indian banks. 2(1).

[6] Ogbadu, dr. E. E., \& Usman, A. (2012). Imperatives of Customer Relationship Management in Nigeria Banking Industry. Kuwait Chapter of Arabian Journal of Business and Management Review, 2(1), 59-72.

[7] P.B REDDY, P. . R., SHALINI. CHENNAMARAJU, S. C., \& SANKAR, D. M. S. (2012). Customer Relationship Management in Banking Sector. International Journal of Scientific Research, 2(12), 80-82. https://doi.org/10.15373/22778179/dec2013/25

[8] Rianto, M. N., Arif, A., \& Nurasiah, T. (2015). CUSTOMER RELATIONSHIP MANAGEMENT DAN PENGARUHNYA TERHADAP LOYALITAS NASABAH BANK: STUDI PADA BANK MUAMALAT INDONESIA M. Nur Rianto Al Arif \& Titin Nurasiah UIN Syarif Hidayatullah Jakarta. 5(1).

[9] Sanjaya, R., Sumarwan, U., \& Kirbrandoko, -. (2015). Hubungan Customer Relationship Management dengan Loyalitas Nasabah (Studi Kasus: PT Bank XYZ Cabang Bogor). MANAJEMEN IKM: Jurnal Manajemen Pengembangan Industri Kecil Menengah, 
10(2), 151-162. https://doi.org/10.29244/mikm.10.2.151-162

[10] Sin, L. Y. M., Tse, A. C. B., \& Yim, F. H. K. (2005). CRM: Conceptualization and scale development. European Journal of Marketing, 39(11-12), 1264-1290. https://doi.org/10.1108/03090560510623253

[11] Suprapty, R., Witjaksono, A., Nugroho, L., Badawi, A., Susanti, M., Mardanugraha, E., \& Ary, W. W. (2021). PERBANKAN (Hasil pemikiran dari Para Dosen Berbagai Perguruan Tinggi di Indonesia). In N. L. Sumitro, Bambang Agus Pramuka (Ed.), Sihsawit Labuhan Batu, PT (2nd ed.). Sihsawit. https://id1lib.org/book/17203232/f9c13a 